Brit. J. industr. Med., 1964, 21, 210.

\title{
EXCRETION OF $p$-NITROPHENOL AND p-AMINOPHENOL IN THE URINE OF A PATIENT EXPOSED TO NITROBENZENE
}

\author{
BY \\ MASAYUKI IKEDA and AKIRA KITA \\ From the Department of Public Health, Faculty of Medicine, Kyoto University, Kyoto, and \\ the Kobe Kaisei Hospital (Franciscan Missionaries of Mary), Kobe, Japan
}

(RECEIVED FOR PUBLICATION NOVEMBER 15, 1963)

\begin{abstract}
An account is given of a patient who had had chronic exposure to nitrobenzene and in whom the metabolites, $p$-nitrophenol and $p$-aminophenol, were present in the urine. A method of separative determination of these two substances in urine is described.
\end{abstract}

A 47-year-old woman, after being exposed to nitrobenzene for 17 months, was admitted to hospital because of headache, nausea, cyanosis, and general weakness. Laboratory study revealed, in addition to methaemoglobinaemia, the presence of $p$-aminophenol as well as $p$-nitrophenol in the urine. Both compounds gradually disappeared from the urine during the two weeks after she was removed from the toxic agent. The fate of methaemoglobinaemia paralleled that of these two compounds.

\section{Case Report}

A 47-year-old woman had been employed for 17 months in a small paint firm where she painted and polished lids of pans with a red paint containing nitrobenzene as solvent.

At the end of March 1963 the workshop was remodelled, and ventilation became rather poor.

On May 17, she complained of severe headache, nausea, vertigo, and numbness in the legs. Her appetite became very poor. Liver damage, hypotension, and cyanosis were recorded by a general practitioner. After five days of rest in bed she felt 'all right' and went back to work.

There was a second attack of severe headache, nausea, and severe general weakness on August 16. This attack forced her to take to her bed and she was admitted to hospital the next day.

On physical examination the patient was emaciated and in obvious distress; the body temperature was normal, the blood pressure was $120 / 72 \mathrm{~mm}$. $\mathrm{Hg}$, and the pulse 70 , regular. The lips and oral mucosa were cyanotic and the sclerae were slightly icteric. The liver was palpable one and a half fingers' breadth below the right costal margin and was tender on pressure. The spleen was palpable two fingers' breadth below the left costal margin and was also tender. There was hyperalgesia to pin-prick on the back of the hands and feet with slight cyanosis, but no thermal changes in the skin were detected. The patient felt 'stiff in the arm' when writing.

After the administration of glucose, vitamin $B_{1}$, vitamin $B_{2}$, and iron preparations, the cyanosis and general weakness disappeared gradually and the numbness in the legs was relieved. Her appetite began to return and her body weight was restored to normal. The patient was discharged after 39 days in hospital with only residual hyperalgesia in the hands and feet.

It should be noted that her friend, a woman of 53 years employed on the same work, was also sent to hospital with similar symptoms two weeks before the admission of the present patient.

\section{Laboratory Investigations}

Urine.-Urine samples were collected every 24 hours. To hydrolyse sulphates and glucuronides of phenols, $1 \mathrm{ml}$. of urine was mixed with $3 \mathrm{ml}$. of $1 / 3 \mathrm{~N} \mathrm{H}_{2} \mathrm{SO}_{4}$ in a $10 \mathrm{ml}$. ampoule, and the ampoule was sealed and heated in a boiling water bath for one hour as described in a previous report (Ikeda, 1964).

Two millilitres (of aliquot) were transferred from the ampoule to a 20 -ml. glass-stoppered bottle containing $15 \mathrm{ml}$. of ether.* The bottle was shaken 400 times per minute for 10 minutes in a shaking apparatus, and then centrifuged to separate the ether layer from the water layer. The ether layer, containing $p$-nitrophenol, was used for the determina-

*Ether should be freshly distilled to make peroxide free. 
Fig. 1.-Changes in the levels of total haemoglobin and methaemoglobin in blood and of $p$ nitrophenol and $p$-aminopheno in urine. The usual daily volume of urine was about 1 litre.

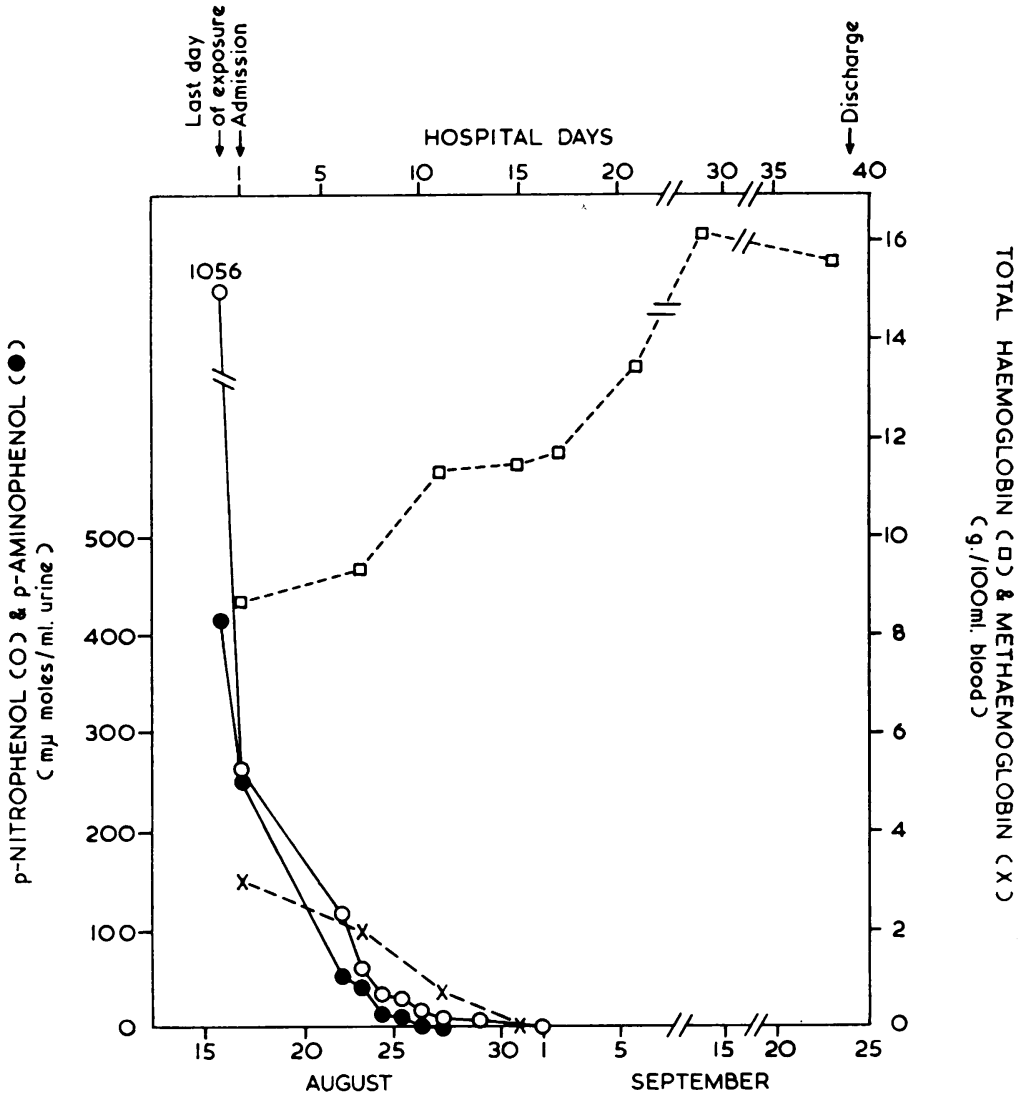

tion of the $p$-nitrophenol concentration by the method of Lawford and Harvey (1953). After the $p \mathrm{H}$ of the water layer in the bottle had been adjusted to 7.0 by adding $0.5 \mathrm{ml}$. of $0.5 \mathrm{M}$ sodium phosphate buffer $(p \mathrm{H} \mathrm{7.0)}$ and $0.5 \mathrm{ml}$. of $2 \mathrm{~N} \mathrm{NaOH}, 15 \mathrm{ml}$. of ether was added. Shaking and separation of the ether layer was carried out as described above. $p$-Aminophenol was assumed to be extracted into the ether layer, and a quantitative determination was performed by the method of Brodie and Axelrod (1948). The colour development of $p$-aminophenol by this method is independent of the presence or absence of $p$-nitrophenol; thus, if desired, $p$-aminophenol can be directly determined with neutralized urine samples omitting the ether extraction of p-nitrophenol.

The changes in urinary concentration of both $p$-nitrophenol and $p$-aminophenol are summarized in Figure 1. The levels of both compounds were very high when the patient was still engaged on her work, namely $1,056 \mathrm{~m} \mu \mathrm{moles} / \mathrm{ml}$. of $p$-nitrophenol and $416 \mathrm{~m} \mu \mathrm{moles} / \mathrm{ml}$. of $p$-aminophenol, and disap- peared gradually during the two weeks in hospital. The quantity of $p$-aminophenol varied in the range of 1 to $\frac{1}{2}$ that of $p$-nitrophenol. The urobilinogen reaction was positive in the first few days. Bilirubin was not detected.

There were no other remarkable findings in the urine of this patient during her stay in hospital.

Blood.-The haemoglobin and methaemoglobin concentrations were determined on venous blood samples by a modification (Hashimoto, 1958) of the method of Evelyn and Malloy (1938).

The blood findings are summarized in Fig. 1 and Table 1. The concentration of methaemoglobin ran parallel with the levels of phenols in the urine until they disappeared after 15 days in hospital. Recovery of the haemoglobin and the red cell count accompanied this change. The white cells and platelets remained normal.

Liver Function.--Enzyme activities were measured as follows: serum alkaline phosphatase after Bessey, 
TABLE 1 BLOOD FINDINGS

\begin{tabular}{|c|c|c|c|c|}
\hline Date & Aug. 17 & Aug. 30 & Sept. 9 & Oct. 21 \\
\hline $\begin{array}{l}\text { Leucocyte count }\left(\times 10^{3} / \mathrm{mm}^{3}\right) \\
\text { Erythrocyte count }\left(\times 10^{6} / \mathrm{mm}^{3}\right) \\
\text { Thrombocyte count }\left(\times 10^{3} / \mathrm{mm}^{3}\right) \\
\text { Reticulocyte count }(\% / 00) \\
\text { Toxic granules }\end{array}$ & $\begin{array}{c}7 \cdot 7 \\
2 \cdot 8 \\
102 \\
120 \\
\text { Present } \\
\text { (abundant) }\end{array}$ & $\begin{array}{r}5 \cdot 0 \\
3 \cdot 4 \\
\text { Absent }\end{array}$ & $\begin{array}{l}5.4 \\
3.8\end{array}$ & $\begin{array}{c}7 \cdot 0 \\
4 \cdot 7 \\
300 \\
7 \\
\text { Absent }\end{array}$ \\
\hline
\end{tabular}

TABLE 2

SERIAL LIVER FUNCTION TESTS

\begin{tabular}{|c|c|c|c|c|c|}
\hline Date & Aug. 19 & Aug. 22 & Aug. 30 & Sept. 10 & Sept. 20 \\
\hline $\begin{array}{l}\text { Albumin/globulin ratio } \\
\text { Icterus index (unit) } \\
\text { Bilirubin (mg./100 ml.) } \\
\text { Total } \\
\text { Indirect } \\
\text { Direct } \\
\text { BSP ( } \% \text { retained at } 30 \mathrm{~min} .) \\
\text { CCF } \\
24 \text { hours } \\
48 \text { hours } \\
\text { Serum alkaline phosphatase (unit) } \\
\text { SGOT (unit) } \\
\text { SGPT (unit) } \\
\text { Total cholesterol (mg. } / 100 \mathrm{ml} .)\end{array}$ & $\begin{array}{l}1 \cdot 15 \\
12 \\
1 \cdot 3 * \\
1 \cdot 0 \\
0 \cdot 3 \\
65 \\
+ \\
++ \\
1 \cdot 9 \\
20 \\
12 \\
100\end{array}$ & $\begin{array}{r}1.05 \\
\overline{+} \\
115\end{array}$ & 7 & $\begin{array}{c}5 \\
0.4 \\
0.4 \\
\text { Negative } \\
6\end{array}$ & $\begin{array}{c}0.9 \\
7 \\
0.5 \\
0.5 \\
\text { Negative } \\
6 \\
+ \\
++ \\
3.0 \\
20 \\
21 \\
150\end{array}$ \\
\hline
\end{tabular}

Bilirubin was not detected in the urine.

Lowry, and Brock (1946), SGOT and SGPT after Reitman and Frankel (1957). Other tests were carried out by the usual methods. The results are summarized in Table 2. From the test on August 19, a marked retention of BSP with a slight increase in the icterus index and indirect bilirubin level were noted.

Paint Analysis.-Distillate at the temperature range of $25-220^{\circ} \mathrm{C}$. from the paint was analysed with a Yanagimoto gas chromatograph*. The result was as follows: nitrobenzene $99.7 \%$, benzene $0.27 \%$. The addition of bromine water to the water suspension of the distillate did not give the flesh colour of tribromoaniline (Jacobs, 1949), and the ultraviolet absorption spectrum of the ethanol solution of the distillate had no broad peak of aniline at $287 \mathrm{~m} \mu$. This evidence indicates the absence of aniline in the paint.

The ultraviolet absorption spectrum was obtained with a Hitachi autographic DU spectrophotometer. Other absorption measurements were made with a Shimadzu DU spectrophotometer.

\section{Discussion}

The previous occurrence of a similar case in a

*We are indebted to Dr. K. Nishida of the Department of Sanitary Engineering, Faculty of Technology, Kyoto University, Kyoto, Japan, for conducting the gas chromatography. 53-year-old female worker on the same process strongly suggested that our patient was likely to be suffering from nitrobenzene poisoning so that investigations including urinalysis could be started before the admission of the patient to hospital.

Contrary to the results of Salmowa, Piotrowski, and Neuhorn (1963), $p$-aminophenol was detected in the urine of our nitrobenzene-exposed patient in fairly high concentration. As $p$-nitrophenol does not give a blue colour when it is treated as $p$-aminophenol by the method of Brodie and Axelrod (1948), the phenolic compound, which is extracted in ether from neutralized urine but not from strongly acid urine and measured as $p$-aminophenol, should not be $p$-nitrophenol. It seems reasonable to assume that the formation of $p$-aminophenol from nitrobenzene, as shown by Parke (1956) in his radioisotope experiment on rabbits and guinea-pigs, occurs even in chronic nitrobenzene intoxication in human subjects. Thus, $p$-aminophenol as well as $p$-nitrophenol should be considered as a metabolite in human subjects chronically exposed to nitrobenzene. The ratio of $p$-aminophenol to $p$-nitrophenol in the urine of the present patient differs, to some extent, from Parke's result (1956), and this difference may be attributable to the difference of species or to a different period of exposure.

Five adult Wistar rats were exposed to nitrobenzene vapour at a concentration of 25 p.p.m. for 8 hours, and the urine excreted by all the animals 


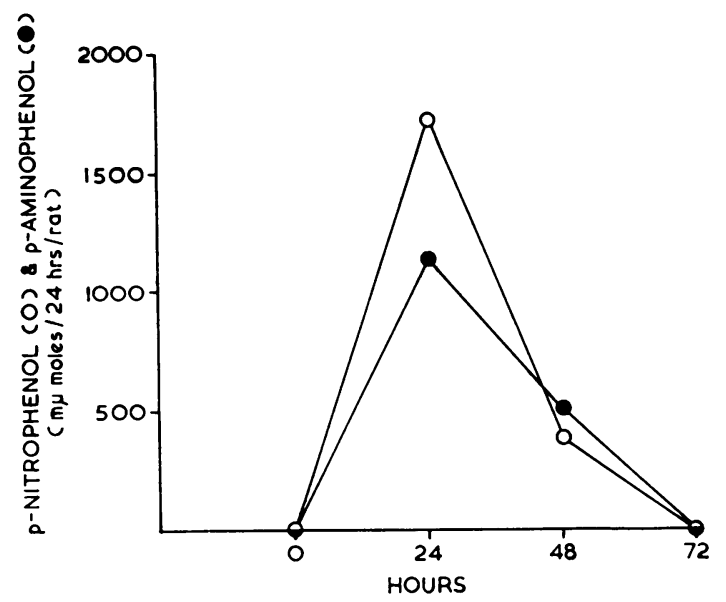

FIG. 2.-Excretion of $p$-nitrophenol and p-aminophenol in the urine of rats exposed to nitrobenzene.

was collected over 24-hour periods. The cage was designed for separate collection of the urine and faeces. The amounts of $p$-nitrophenol and $p$-aminophenol were determined by the method described above, and the results are shown in Figure 2. The ratio of $p$-aminophenol to $p$-nitrophenol corresponded with that of the present human case.

Bearing in mind Yoshida's findings in the optic nerves of rabbits injected with nitrobenzene (1962), the hyperalgesia on the backs of the hands and feet might be due to degenerative changes of the nerves, although the fundi of our patient were quite normal on ophthalmological examination. From the data shown in Table 2, it can be assumed that the jaundice and enlargement of the spleen were due to increased destruction of haemoglobin and that the liver disorder is secondary, but the true aetiology is still unknown.

We are grateful to Professor M. Nishio of the Department of Public Health, Faculty of Medicine, Kyoto University, Kyoto, Japan, for his interest in this work.

\section{REFERENCES}

Bessey, O. A., Lowry, O. H., and Brock, M. J. (1946). J. biol. Chem., 164, 321.

Brodie, B. B., and Axelrod, J. (1948). J. Pharmacol. exp. Ther., 94, 22. Evelyn, K. A., and Malloy, H. T. (1938). J. biol. Chem., 126, 655. Hashimoto, T. (1958). Jap. J. Nation's Health, 27, 385.

Ikeda, M. (1964). J. Biochem. (Tokyo), in press.

Jacobs, M. B. (1949). The Analytical Chemistry of Industrial Poisons, Hazards and Solvents, 2nd ed., p. 709. Chemical Analysis, edited by $B$. Clarke and I. M. Kolthoff. Interscience Publishers, New York.

Lawford, D. J. and Harvey, D. G. (1953). Analyst, 78, 63.

Parke, D. V. (i956). Biochem. J., 62, 339.

Reitman, S., and Frankel, S. (1957). Amer. J. clin. Path., 28, 56.

Salmowa, J., Piotrowski, J., and Neuhorn, U. (1963). Brit. J. industr. Med., 20, 41 .

Yoshida, T.'(1962). Jap. J. industr. Health, 4, 262. 